New Yiddish Library 
The New Yiddish Library is a joint project of the Fund for the Translation of Jewish Literature and the National Yiddish Book Center.

Additional support comes from The Kaplen Foundation, the Felix Posen Fund for the Translation of Modern Yiddish Literature, and Ben and Sarah Torchinsky.

SERIES EDITOR: DAVID G. ROSKIES 


\section{The End of}

Everything

DAVID BERGELSON

TRANSLATED AND WITH

AN INTRODUCTION BY

JOSEPH SHERMAN

YALE UNIVERSITY PRESS

NEW HAVEN AND LONDON 
Copyright (C) 2009 by the Fund for the Translation of Jewish Literature and the National Yiddish Book Center.

All rights reserved.

This book may not be reproduced, in whole or in part, including illustrations, in any form (beyond that copying permitted by Sections I07 and Io8 of the U.S. Copyright Law and except by reviewers for the public press), without written permission from the publishers.

Set in Scala and Scala Sans type by The Composing Room of Michigan, Inc.

Printed in the United States of America.

Library of Congress Cataloging-in-Publication Data

Bergelson, David, I884-I952.

[Nokh alemen. English]

The end of everything / David Bergelson ; translated and with an introduction by Joseph Sherman.

p. cm. - (New Yiddish library)

Includes bibliographical references.

ISBN 978-0-300-II067-8 (pbk.: alk. paper)

I. Sherman, Joseph. II. Title.

PJ5I29.B45N6I3 2010

$839^{\prime} .133-\mathrm{dc} 22$

2009022478

A catalogue record for this book is available from the British Library.

This paper meets the requirements of ANSI/NISO Z39.48-I992 (Permanence of Paper).

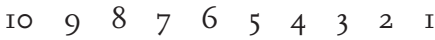

